\title{
ソイルセメントの原材料としての粘性土の ときほぐしについで* \\ DISINTEGRATION OF COHESIVE CLAY LUMPS USED AS SOIL-CEMENT
}

\author{
枷 場 重 正**.川 村 満 紀*** \\ By Shigemasa Hasaba and Mitsunori Kawamura
}

\section{1. まえがき}

道路路盤材料としてソイル セメントは早くから注目 され, 道路の構造的機能上からも効果的であることが指 摘されている1),2)。

しかしソイル セメントに使用する土は一般に粗粒子 土または light clay に限られ, ポルトランド セメント による粘性土の安定処理は通常不可能とされている。

そのおもな原因は粘性土を十分小さな土粒子集合体に ときほぐす注)ことのできるプラントがないためである。

わが国における路床土は気候性土，火山灰，沖積土な ど粘性をもったものが多いが，上述のような理由で一般 にこれら粘性土をポルトランド セメントによって経済 的に安定処理することは不可能とされ, 現場近くに砂質 土などが容易に得られる場合にのみ安定処理を行なって いるようである。しかし土の物理的性質にのみ着目すれ ば，いかなる土もときほぐすことによってソイル セメ ントとして有効に使用できる。このような考え方からす れば, 劣悪な粘性土も乾燥し, ときほぐすことによって ソイルセメントとしての道路路盤への使用可能性につ いて検討することはわが国の路床土の特徴よりみて意義 あると考えられる。またソイルセメントの性質に影響 をおよぼす要因については多数の研究がなされてきた が, ときほぐしの程度がンイル セメントの一軸圧縮強 度におよぼす影響に関しては 2,3 の研究 ${ }^{3), 4)}$ がみられ るにすぎず, これらの研究もつねに同一の粒度分布の試 料が得られているかどうかという点で実験方法に欠かん があるようである。

とくに粘性土を使用したソイル セメントに関する実 験ではときほぐし程度が非常に重要な要素であり, Highway Rearch Board's Committee によるソイル セ

*第 22 回土木学会年次学術講演会 (昭和 42.5) にて一部 発表

** 正会員 工博 金沢大学教授 工学部土木工学教室

*** 正会員 工修 金沢大学講師 工学部土木工学教室

注）従来粘性土塊を機械的により 小さな集合体に 分離する操 作に「粉粋 (pulverization)」という用語が使用されて いるが，土粒子の集合体の大きさをより小さい集合体に “分散”させるという意味を強調するために，ここでは 「ときほぐし (disinlegration)」という語を使用する。 メントの定義においても“粉砕された土（pulverized soil)”を使用することが明確化されているにもかかわら ず,これまでの実験, 研究では“粉砕の程度”のあいま いなものが多い。米国の Portland Cement Association においても室内実験のための土試料の調整法として，土 粒子本来の大きさを減少させないように粉砕し $4.76 \mathrm{~mm}$ ふるいで一応ふるい, 実際の各種試験には $3 / 4$ in 以下 $4.76 \mathrm{~mm}$ 以上の試料を加えることとしている5)。しかし ここにおいてもときほぐしの方法や程度については言及 されていない。

このように粘性土をソイル セメントとして有効に使 用するという面からも，また室内実験において土粘子の 粒度調整法に普遍性をもたせる面からも粘性土のときほ ぐしの機構について解明されねばならないと思われる。 粘性土のときほぐし機構については粘性土塊の力学的性 質との関連において論じなければならないが, 粘性土塊 の力学的性質はきわめて複雑なものであるばかりでな く，材料全体になされた仕事量の測定は実験上かなり困 難である。ここでは粘性土塊の物理的, 幾何学的性質と して含水比と大きさをとりあげ，また粘性土塊にあたえ る仕事量を定性的に示すものとして機械の回転速度（次 節参照) の大小をとりあげ，これら要因とときほぐし効 果の関係について実験的に明らかにする。

このような目的で，まず粘性土をときほぐす機械を製 作し, 金沢市卯辰山産の粘性土と関東ロームについて上 述のような観点から行なった 2,3 の実験結果について 述べる。

また最後に圧縮強度からみて，このような方法でとき ほぐされた粘性土はンイルセメントとして十分使用可 能であることを示す。

\section{2. 実 験 概 要}

\section{(1) 装}

実験に際し使用した機械器具はまずときほぐし試験用 試料作製装置 (写真一1) および本研究用として試作し たときほぐし機 (写真一2) である。

写真一1 に示す装置は $40 \mathrm{~cm} \times 40 \mathrm{~cm} \times a \mathrm{~cm}$ (ここで は供試体の大きさによって， $a$ として $3,4,5$ の 3 種類 
写真-1
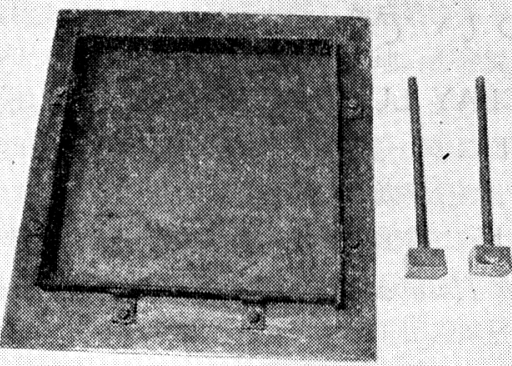

を用いている）の粘性土板が作製できるように高さ $a$ $\mathrm{cm}$ で $40 \mathrm{~cm}$ 長さのカラーが底板（すべて鋼製）にとり つけられ，写真に示寸突き棒によって突き固められるよ うにしたものである。

後者のときほぐし機（原動機：特殊分捲三相交流モ一 ター 1 PS）は，その横断面は 図一1 に示すようなもの である。

この図で(1)のヘッドが軸(2)を中心にして回転し，その 表面に固定されたロッドと(3)の外壁に固定したロッド間 に㧍いてつぎの 3 種の作用によって，上方より投入され
写真-2

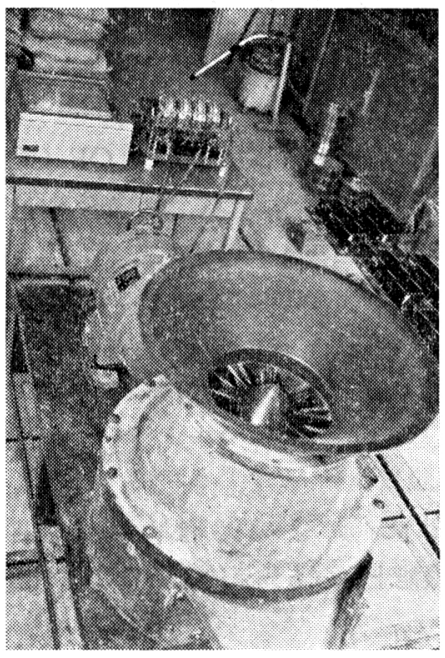

た粘性土塊がとき

ほぐされるものと 考えられる。すな わ第 1 注回転寸 るロッドによる打 撃，第 2 汇回転口 ッドと固定ロッド 間に扔けるせん断 （回転速度が大な るとき湟撃せん 断，小さいときは 静的せん断と考元 られる)，第 3 に ヘッドの面と外壁 間における一種の せ九断（機械下部 に扮いてとくに著しいと考えられる）の 3 つの作用であ る。

また，ときほぐし効果を評価するために行ならふるい 分け試験装置は JIS A 1204 に規定されている一連の子 るいである。

\section{（2）原材料の物理的性質}

本実験に使用した土試料は金沢市卯 唇山産および千葉市産関東ロームであ り，それらの物理的性質は表-1 亿示 すとおりである。

\section{（3）実験方法}

ときほぐし試験用粘性土供試体とし て一辺 $a \mathrm{~cm}$ (ここでは $a$ として 3,4 ， 5 の 3 種類を使用した）の立方体を用 いるため，上述の試料作製用型わく中 に最適含水比になるように調整された 土試料を 2 層に入れ，1 層あたり全面 均一に 200 回突き棒（重量 $1100 \mathrm{~g}$ 写 真一1 参照）で突き固めた。

ここで 200 回とい5回数は予備実験 によって乾燥密度が最大乾燥密度にな るように決定された。200 回といら值

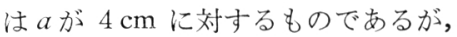

単位: $\mathrm{mm}$

表一1 使用土の物理的性質

\begin{tabular}{|c|c|c|c|c|c|c|c|c|}
\hline 試 料 & & No. 1 & No. 2 & No. 3 & No. 4 & No. 5 & No. 6 & No. 7 \\
\hline $\begin{array}{l}\text { 三角座標に上る分類 } \\
\text { 液 性 限 界 }(\%)\end{array}$ & 口 & $\begin{array}{cc}- & \text { 厶 } \\
72.3 & \end{array}$ & $\begin{array}{c}\text { シルト質ローム } \\
66.8\end{array}$ & $\begin{array}{c}\text { 砂質口- } 0 \\
128.0\end{array}$ & $\begin{array}{c}\text { シルト質ローム } \\
70.5\end{array}$ & $\begin{array}{c}\text { 粘土質口ーム } \\
64.7\end{array}$ & 粘 46.6 土 & $\begin{array}{c}\text { ンルト質ローム } \\
71.2\end{array}$ \\
\hline 塑 性 限 界 (\%) & & 40.8 & 47.4 & 88.3 & 36.9 & 39.7 & 30.6 & 45.2 \\
\hline 塑 性 指 数 & & 31.5 & 19.4 & 39.7 & 32.6 & 25.0 & 16.0 & 26.0 \\
\hline 最適合水比 $(\%)$ & & 38.5 & 35.5 & 91.0 & 71.8 & 36.0 & 28.0 & 32.0 \\
\hline 最大乾燥密度 $\left(\mathrm{g} / \mathrm{cm}^{3}\right)$ & & 1.27 & 1.31 & 0.79 & 1.39 & 1.30 & 1.44 & 1.34 \\
\hline 比重 & & 2.59 & 2.64 & 2.85 & 2.53 & 2.64 & 2.60 & 2.64 \\
\hline
\end{tabular}

No. 3 : 関東ローム 
$3 \mathrm{~cm}, 5 \mathrm{~cm}$ の場合は突き固められた粘性土の容積に比例 させておのおの 150 回，および 250 回とした。このよう にして突き固められた粘性土板を鋼製のナイフによって 一辺 $a \mathrm{~cm}$ の立方体に細分したのち, 立方供試体の含水 比が所定のものになるように乾燥炉中で乾燥させた。こ のようにして得られた所定の含水比の立方供試体をとき ほぐし機の投入口上 $40 \mathrm{~cm}$ の高さより 5 秒間に 1 個の割 合で落下投入させた。

なお機械のヘッドの回転速度は $125,250,375,500$, 625 r.p.m.の 5 段階に変化させている。ときほぐされた 土試料はただちにふるい分け試験に供した。

\section{3. 粘性土のときほぐし効果}

\section{（1）ときほぐし効果の表示法}

ときほぐし効果の表示法として，ここではときほぐさ れた粘性土塊の粒度分布状態を示す粒度加積曲線および 細かさの程度を示すものとして比表面積 $(S), D . N$. 值 (Disintegration Number) を使用した。

$1 \mathrm{~cm}^{3}$ の試料のもつ総表面積として定義される比表面 積 $S$ は

$$
S=f\left(\sum n d^{2} / \Sigma n d^{3}\right)
$$

ここで,

$$
\begin{aligned}
& f: \text { 形態係数 } \\
& d: \text { 粒子径 } \\
& n: \text { 径 } d \text { をもつ粒子の数 }
\end{aligned}
$$

ふるい分け試験の結果から $S$ を求めるために, $d_{n} \sim$ $d_{n+1} \mathrm{~mm}$ の粒子はすべて $\left(d_{n}+d_{n+1}\right) / 2$ の球であるとし て,つぎの式 (2) なる近似式を導いた。

$$
S \doteqdot f \Sigma \frac{r_{n+1}, n}{100 \cdot d_{m}}
$$

$$
\text { ここで, }
$$

$r_{n+1},{ }_{n}:$ ふるい $d_{n} \sim d_{n+1} \mathrm{~mm}$ の残留率

$$
d_{m}=\left(d_{n}+d_{n+1}\right) / 2
$$

また D.N. 值よは次式で定義されるものである。

$$
D . N .=\frac{\Sigma(\text { 加積残留率 })}{100}
$$

本論ではおもに式 (3) で表わされるD.N. を，ときほ ぐし程度を判断する尺度とした。

\section{(2) 実験結果と考察}

a）粘性土塊の含水比がときほぐし効果におよぼす影

\section{響}

ときほぐされた粘性土の粒径加積曲線を土試料 No. 1 について示すと図一2のようになる。ときほぐし時の供 試体の含水比が粒度分布におよぼす影響は回転速度によ って多少異なるけれども, 図一2 のように含水比の減少 とともに曲線は全体として粒径減少の方向に移行する。 このような粒径加積曲線からは各種試料の粒度特性は不 明確であるが，D.N. 值や比表面積を計算するとより明 確になる。
図一2 粒径加 積曲 線

（土試料：No. 1, 回転速度 625 r.p.m, 供試体：一辺 $4 \mathrm{~cm}$ )

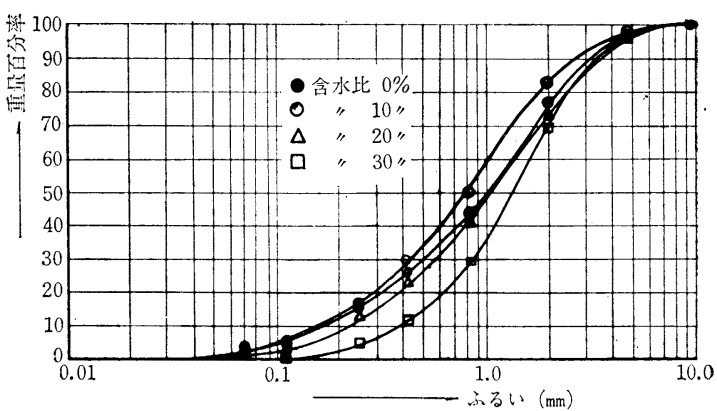

図一-3 含水比と比表面積の関係 （土試料：No. 1)

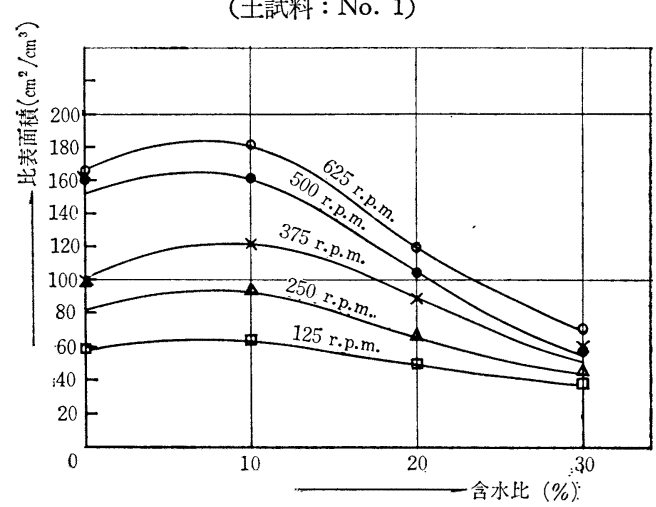

図一4 含水比と D.N. の関係 (土 : No. 1)

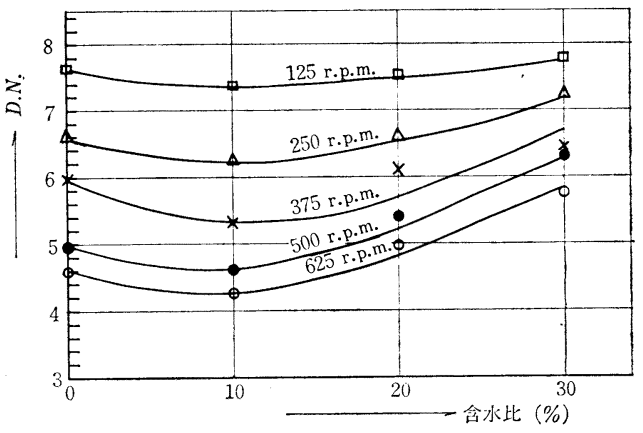

図一3 から明らかなように一定の回転速度によって立 方供試体（一辺 $4 \mathrm{~cm}$ ) をときほぐした場合, 生ずる粒 子の比表面積は含水比によって著しく異なる。No. 1 試 料については含水比が $10 \%$ 前後のとき最大となる。

$D . N$. 值によって評価すると図一4のように含水比の 減少とともに小さくなり，10\% 前後で最小になる。こ れらの図から明らかなよらに，いずれの回転速度におい ても含水比が $10 \%$ 前後で D.N. 值が最小值 (比表面積 は最大值）をもつ曲線となる。物理的性質が多少異なる 他の粘性土については最大乾燥密度の小さいものほど全 般に D.N. は小さくなるが曲線自身の形は同様でいずれ も $10 \%$ 前後で最小になる (図一5 参照)。 
図一5 各粘性土の含水比と D.N. の関係

（供試体：一辺 $4 \mathrm{~cm}$, 回転速度 : 500 r.p.m.)

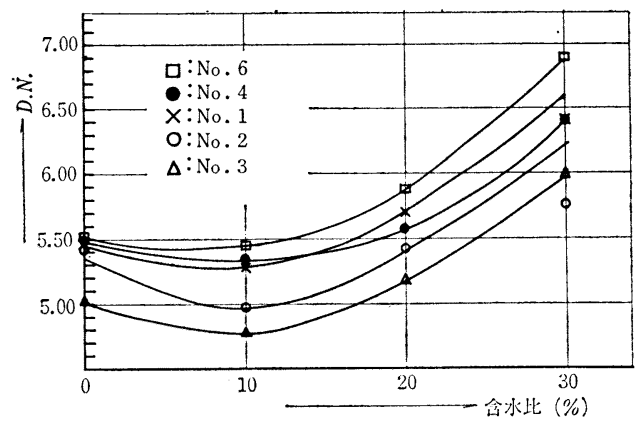

すなわち本実験で使用した粘性土（関東口ームは除 く）ではときほぐし時の含水比が $10 \%$ 前後のとき, も っともときほぐし効果があがるといえる。

b） ヘッドの回転速度とときほぐし効果の関係

回転速度がときほぐし効果におよぼす影響について明 らかにするために, 回転速度と比表面積の関係をえがく と図一6のようになり，また D.N. 值との関係について は図一7のようになる。図一7 が示すように各含水比に おいて回転速度の増加とともに比表面積は直線的に大き くなり，D.N. 值は直線的に小さくなる。また $10 \%$ ま では含水比が小さいものほどこう配は大きくなり，0\% のものは $10 \%$ のものとほぼ等しいこう配となるようで ある。

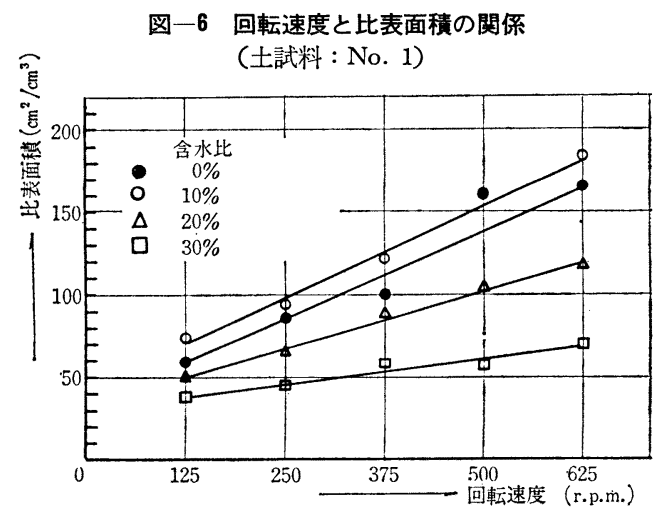

図-7 回転速度と D.N. の関係

（土試料：No. 1 , 供試体：一辺 $4 \mathrm{~cm}$ )

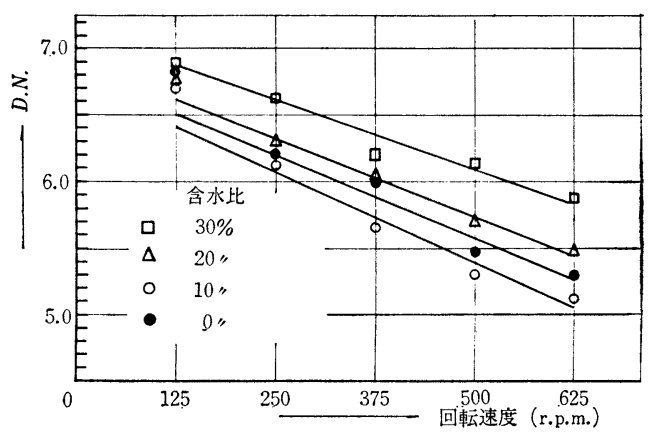

c） 粘性土塊の大きさとときほぐし効果の関係 固体破砕の理論では粉砕に有効であった正味仕事量と 粉砕効果との間には一定の関係が成立すると考えられ, 中川によると稜の長さ $D$ の立方体の材料の粉砕に要す る仕事量 $W$ は

$$
\begin{aligned}
W & =C_{1} D^{3}+C_{2} D^{2} \\
C_{1}, C_{2} & : \text { 定数 }
\end{aligned}
$$

粘性土塊のような塑性材料のときほぐしにおいても立方 体の一辺 $D$ と仕事量 $W$ の間には何らかの関係が存在す るはずであるけれども，W の測定にはかなりの困難が ともなう。

ここではときほぐし時に測定された消費電力から，一 辺 $3 \mathrm{~cm}, 4 \mathrm{~cm}, 5 \mathrm{~cm}$ の各立方供試体 1 個をときほぐすに 要する仕事量を算出した結果, 表一2 のようになった。

表一2 供試体一辺の大きさと仕事量

\begin{tabular}{c|c|c|c|c}
\hline \hline 回轱速度 & $W, D . N$. & $3(\mathrm{~cm})$ & $4(\mathrm{~cm})$ & $5(\mathrm{~cm})$ \\
\hline 625 & $W\left(\times 10^{6} \mathrm{erg}\right)$ & 0.16 & 0.15 & 0.18 \\
(r.p.m.) & $D . N$. & 5.3 & 5.4 & 5.2 \\
\hline 375 & $W\left(\times 10^{6} \mathrm{erg}\right)$ & 0.10 & 0.13 & 0.12 \\
(r.p.m.) & $D . N$. & 6.0 & 5.9 & 5.9 \\
\hline 250 & $W\left(\times 10^{6} \mathrm{erg}\right)$ & 0.12 & 0.18 & 0.14 \\
(r.p.m.) & $D . N$. & 6.3 & 6.4 & 6.4 \\
\hline
\end{tabular}

$D:$ 立方供試体一辺の長さ，W: 仕事量

この表から明らかなように，ある回転速度において各供 試体の D.N. 值はほぼ等しい（各場合において一定のと きほぐし効果があがっている)。このことから，本実験で 行なった範囲の大きさの立方供試体では仕事量 $W$ は一 辺の長さDの大きさに関係なく一定であるといえよう。 すなわち弾性固体の破砕においては $W$ とDの間にたと えば上述のような式が成立するけれども, 締め固め粘性 土の場合は多少の供試体の大きさの変化は仕事量にほと んど影響をおよぼさないと結論できる。つぎに立方体の 一辺の長さとときほぐし効果の関係を明らかにするた内 に, 一辺 $3 \mathrm{~cm}, 4 \mathrm{~cm}, 5 \mathrm{~cm}$ の立方供試体についてとき ほぐし試験を行ない, 図一8, 図一9 のような結果を得 た。図一8 が示すように，いずれの含水比においても，

図一8 供試体の大きさが D.N. におよぼす影县 （土試料 : No. 4 , 含水比 : $30 \%$ )

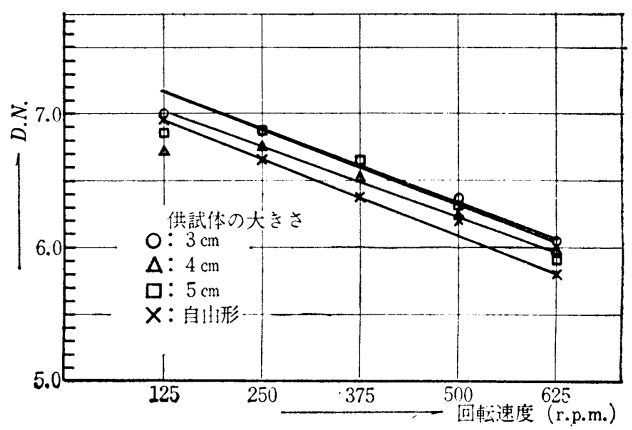


図一9 供試体の大きさと含水比-D.N. 関係

(土試料 : No. 4, 回転速度 : 625 r.p.m.)

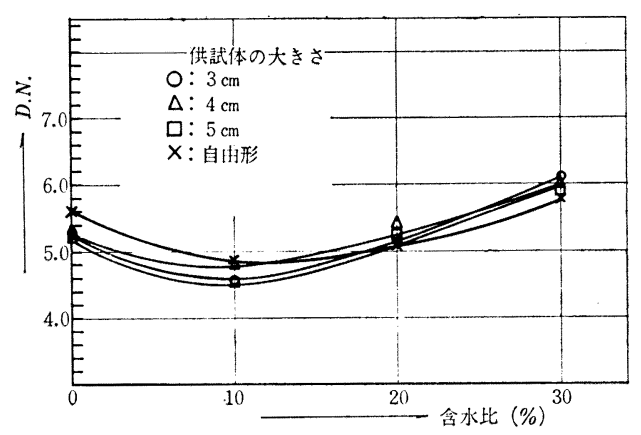

またいずれの大きさの供試体においても，回転速度が低 下寸るにしたがってD.N. 值はほぼ直線的に低下してい る。またときほぐし効果の最適含水比については, 図一 9 よりいずれの大きさの供試体も含水比 $10 \%$ 前後で $D . N$. 值が最小となる。すなわち, ときほぐし前の粘性 土塊の大きさに関係なく, ときほぐし効果の最適含水比 は $10 \%$ 前後であるといえる。さらに図一8, 図一9上 り各回転速度において, 供試体の大きさによって D.N. 值にほとんど差がないことがわかる。結局回転速度一定 といら条件のもとでは，ときほぐされる粘性土塊の大き さが多少変化してもときほぐし効果にほとんど差がな w。

\section{4. 関東ロームのときほぐしについて}

関東ロームの最適含水比は他の粘性土にくらべて非常 に高く(表一1 における No. 3 参照), ときほぐし時の 含水比を $0 \sim 96.5 \%$ の広範囲に変化させた。図一10 図 一13 が示すように, 含水比抒よび回転速度と D.N. 值ま たは比表面積との関倸は他の粘性土とほぼ同様である。 この場合は含水比が 10 20\% でもっともときほぐし効 果があがっている。また回転速度が大きくなると比表面 積は大きくなり，D.N. 值はほぼ直線的に小さくなる。

図一11 から含水比が $60 \%$ 以下では回転速度の増加と ともに比表面積は急に大きくなるが, 含水比の大きい 80

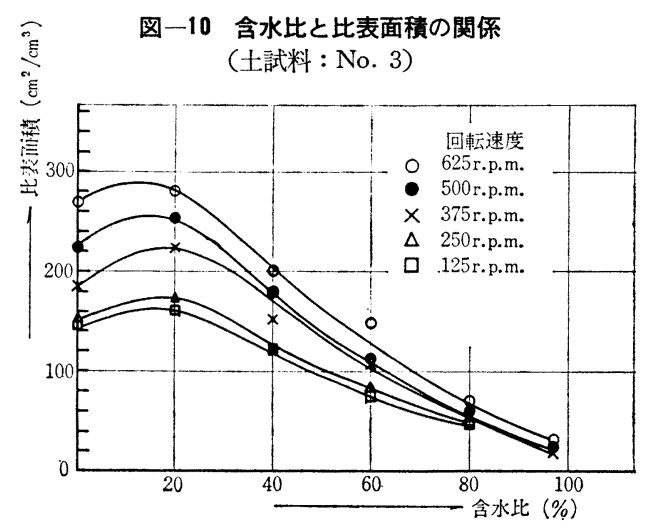

図一11 含水比と D.N. の関係 (土試料 : No. 3)
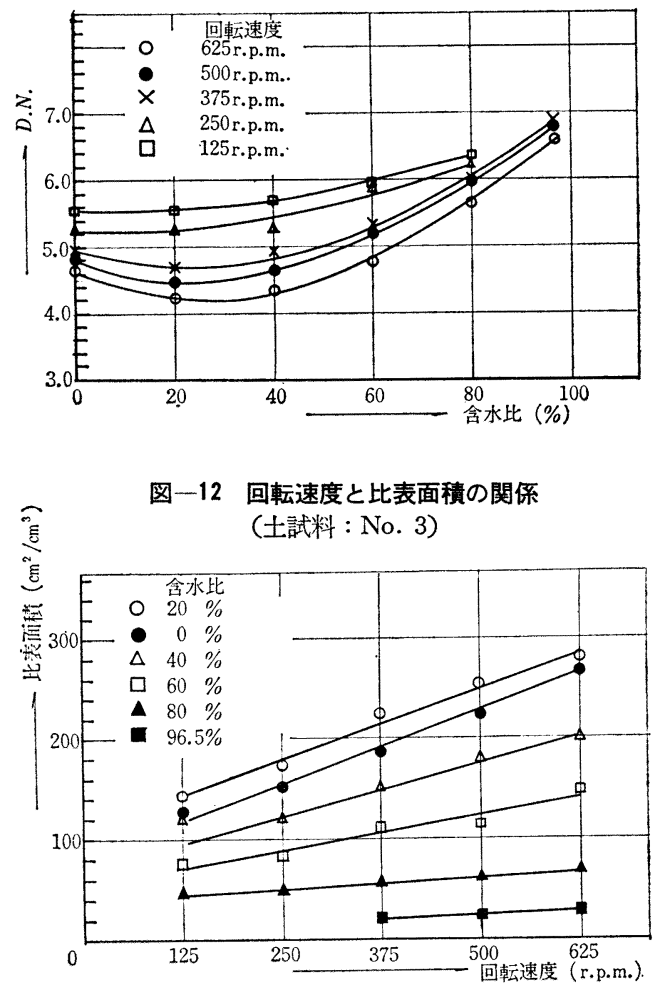

図-13 回転速度と D.N. の関係

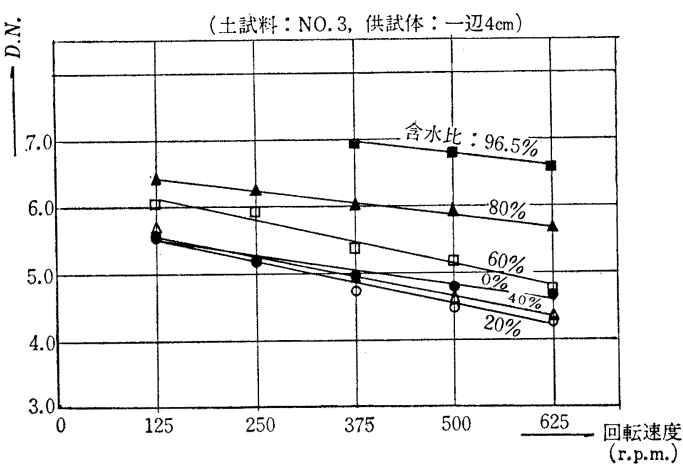

\%, 96.5\% では回転速度の増加にともなう比表面積の増 加割合は含水比の小なるものにくらべて小さい。このこ とは含水比の大きいものでは回転速度を大きくして, 単 位時間にあたえるときほぐしのためのエネルギー量を大 にしてもさほどときほぐしが進展しないことを示してい る。

\section{5. ときほぐし粘性土を使用したソイル セメン トの圧縮強度}

3., 4. において, 粘性土の物理的性質がときほぐし効 果におよぼす影響について明らかになった。実際問題と してはこのようなときほぐし粘性土を使用したソイル 
セメントの道路舗装用としての耐久性およびくり返し荷 重をはじめとする種々の荷重条件下における変形特性な どが重要である。ここでは 3.において述べた各種の D.N. 值をもつ粘性土試料を使用したソイルセメント の一軸圧縮強度を求めた結果, ある程度のときほぐし効 果が得られておれば，10\% 前後のセメント量で道路路 盤用として十分使用可能であることが示された。

\section{(1) 実験装置および方法}

C.B.R. 試験用の載荷装置を使用し,プルービングリン グによって載荷重を測定した。一軸圧縮試験用供試体は B.S. 1924-1957 にしたがい，直径 2 in, 高さ 4 in の円 柱体を使用した。ときほぐされた粘性土にただちに所定 量のセメント(ここでは乾燥土試料に対する重量百分率 として $5 \%$ および $10 \%$ の 2 種類）を添加し, 最適含水 比になるまで水を加えながら 15 r.p.m. の回転速度のア インリツヒ型ミキサを用いて試料 $5 \mathrm{~kg}$ につき 5 分間混 合した。供試体作製法は B.S. 1924 による静的方法を採 用した。すなわち JIS A 1210 の突き固め試験の結果よ り得られた最大乾燥密度の供試体になるように所定量の 試料を 3 層に分けて 2 つ割りモールド（内径 2 in, 高さ 7 in) につめ, プラグをそら入してジャッキによって高 さ 4 in の供試体が得られるように加圧したあと, 押し 出した。成形後供試体は温度 $20^{\circ} \pm 3^{\circ} \mathrm{C}$, 相対湿度 $85 \%$ の恒温恒湿室において7 日間養生したのち試験に供され た。一軸圧縮試験はひずみ速度を一定にして $\left(10^{-2} / \mathrm{min}\right)$ 行なわれた。実験結果はすべて 2 個の平均值である。

\section{(2) 実験結果亡考察}

原材料である粘性土のときほぐしの程度が一軸圧縮強 度におよぼす影響を明らかにするために, セメント量 5 $\%, 10 \%$ について D.N. 值と一軸圧縮強度の関係をえ がくと 図一14, 図一15 のようになる。

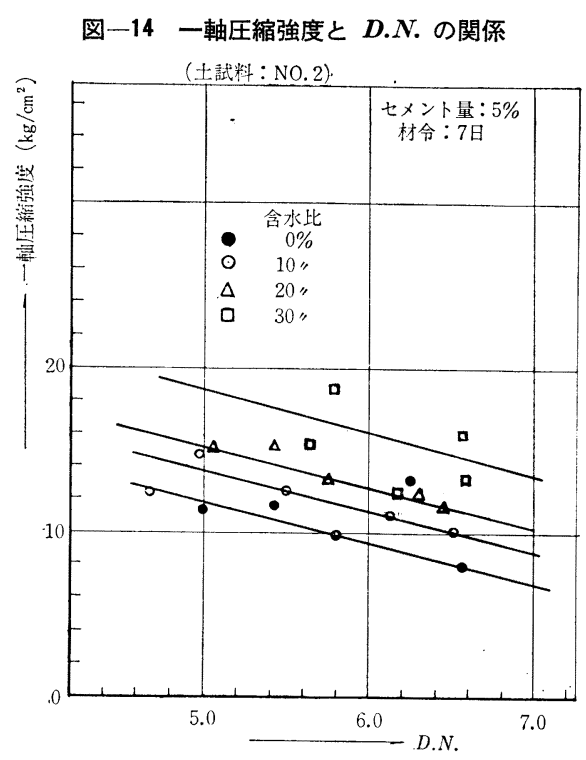

図一15 一軸圧縮強度と D.N. の関係 (土試料: No. 2)

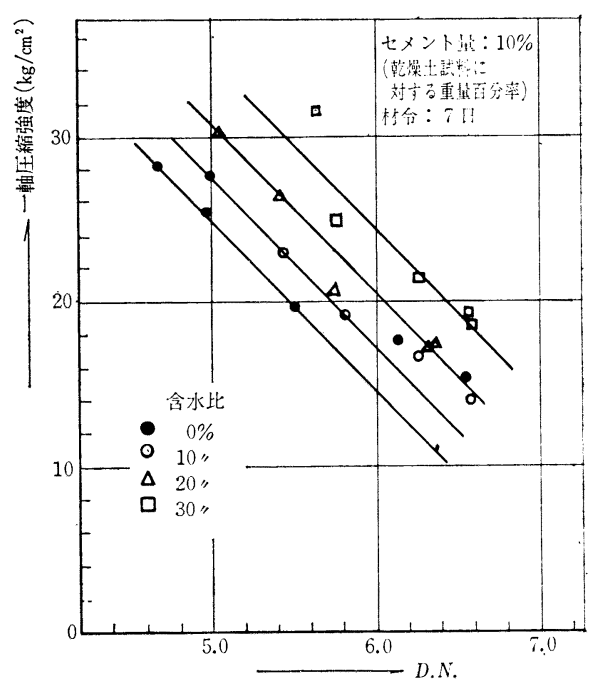

これらの図から明らかなように D.N. 值が小さくなる にしたがって直線的に圧縮強度は增大寸る。圧縮強度の 増大割合はセメント量 10\% の方が5\%よりもはるかに 大きい。これらの図から得られるもう1つの特徴は同一 の D.N. 值をもつ試料でもときほぐし時の含水比が異な れば一軸圧縮強度も異なるといら点である。すなわち， $\sigma_{f}-D . N$. 関係がときほぐし時の含水比によってたがい にほぼ平行な直線になる $(2,3$ 直線からはずれる点が存 在してはいるが)。

本実験で使用した範囲の含水比 (30 0\%) ではときほ ぐし程度が同一であってもときほぐし時の含水比が大な るほど圧強強度も大になるといえる。

水浸 ( 6 日間非水浸, 1 日水浸) の場合の一軸圧縮強 度は 図一16 に示される。図一16 からわかるように， D.N. の差による強度の差は非常に小さくなるが, とき ほぐし時の含水比による差は非水浸のものより大きくな り, 同じ D.N. 值に対して $30 \%$ は $0 \%$ の 2 倍近くの強 度を示す。これはセメントの水和によって生ずるゲルや

\section{図一16 一軸圧綰強度と D.N. の関係} ( 6 日間非水浸, 1 日水浸)

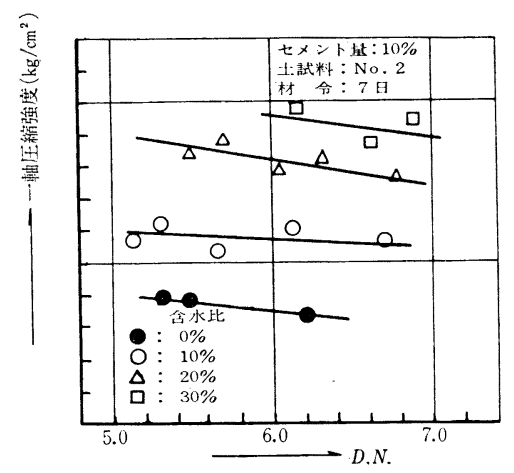


$\mathrm{Ca}^{++}$イオンの拡散の程度が含水比によって異なるため と考えられる。このことはときほぐし, 乾燥の両面から 考えて有利な特性であり, ソイル ライム工法において はすでに粘性土中のイオン拡散の現象が実験的に確かめ られ，また実用上この現象が有利に働くことが認められ ている7)。

イギリスの Road Research Laboratory では 1 週間 養生の圧縮強度の基準を $17.5 \mathrm{~kg} / \mathrm{cm}^{2}$ (250 psi) 以上と していることからすれば，セメント量 10\% では本実験 におけるときほぐし程度で舗装用ソイル セメントとし て十分使用可能であろう。セメント量 $5 \%$ の場合はほと んど上述の基準值より多少小さくなっているが，10\% の場合はほとんど $17.5 \mathrm{~kg} / \mathrm{cm}^{2}$ 以上の圧縮強度が得られ ていることから考えて，5１0\% のセメント量でときほ ぐし時の含水比を $30 \%$ 程度まで高め, 回転速度をあげ てD.N. 值を小さくすればソイル セメントとして経済 的な面からも十分使用できると考えられる。

\section{6. 結論}

自然含水比の高い粘性土をセメントによって経済的に 安定処理できるかどらかはンイルセメントにおいて解決 されねばならない大きな問題の一つである。

本論文ではそのような粘性土もある程度の乾燥, とき ほぐしによってソイル セメントとして十分使用可能で あることを示した。したがって本論文は粘性土のときほ ぐしという点に重点が置かれており, それを使用したソ イルセメントの圧縮強度特性は道路路盤としての使用
可能性を検討するための資料にすぎない。ときほぐし粘 性土を使用したソイル セメントの圧縮強度特性をはじ めとする物理的, 力学的諸性質については今後明らかに されねばならない問題であろら。

本研究は科学研究費の補助によって行なったものであ り, 実験に際し, 久保田・直江・池田・北・東・熊野・ 中村・西川の諸君の協力を得, また本稿をまとめるにあ たり金沢大学大学院生 大深伸尚君に手数をかけたこと を付記し感謝の意を表する。

\section{参 考 文 献}

1）山内豊聡：“路盤材料とその構造的機能について”, 材料 Vol. 16, No. 165, June 1967.

2) Childs, L.D. : "Tests of Concrete Pavement Slabs on Cement-Treated Subbase" H.R.R. 60 Rigid Pave ment Design, 1963, p.p. 50 53.

3) Grimmer, F.J. and Ross, N.F.: "The Effect of Pulverization on the Quality of Clay-Cement" Proceedings, 4 th Internat'l. Conf. Soil Mechanics and Foundation Eng., London, Vol. 2, pp. 109-13, 1957.

4) Catton, Miles D. : "Effect of Soil Lumps in Compacted Soil-Cement", Road Constr., Vol. 22, No. 5, p. 148, May 1, 1944.

5) Portland Cement Association: "Soil-Cement Laboratory Handbook"

6) 久保・水渡 - 中川・早川 : “粉体 (理論と応用)”, 丸善, 昭 37 .

7) Davidson, L.K., Demirel, T. and Handy, R.L. : "Soil Pulverization and Lime Migration in Soil-Lime Stabilization” H.R.R. No.92, 1965 pp. 103 126.

(1967.9. 29. 受付) 